\title{
Self-Enhancement
}

\section{Food for Thought}

\author{
Constantine Sedikides and Aiden P. Gregg \\ University of Southampton, Southampton, England, United Kingdom
}

\begin{abstract}
Self-enhancement denotes a class of psychological phenomena that involve taking a tendentiously positive view of oneself. We distinguish between four levels of self-enhancement-an observed effect, an ongoing process, a personality trait, and an underlying motiveand then use these distinctions to organize the wealth of relevant research. Furthermore, to render these distinctions intuitive, we draw an extended analogy between selfenhancement and the phenomenon of eating. Among the topics we address are (a) manifestations of self-enhancement, both obvious and subtle, and rival interpretations; (b) experimentally documented dynamics of affirming and threatening the ego; and (c) primacy of self-enhancement, considered alongside other intrapsychic phenomena, and across different cultures. Self-enhancement, like eating, is a fundamental part of human nature.
\end{abstract}

Many thinkers have remarked that human beings hold an excessively flattering view of themselves and of things associated with the self. The intellectual foundation for this viewpoint was laid by the Cyrenaics (Tatarkiewicz, 1976), the Epicureans (De Witt, 1973), and the Sophists (Skoyles, 1998), and it was strengthened by Renaissance philosophers (Macfarlane, 1978). Hobbes (1651/1991), in his portrait of man as a self-interested beast, affirmed that "Men [are] vehemently in love with their own new opinions" (p. 48). Mandeville (1705) believed that humans place a high premium on themselves and expect others to view them in the same manner. This thinking is echoed in Leibnizian optimism (1710/1985) and in the utilitarian tradition of Bentham (1785/1982) and John Stuart Mill (1863/2004).

More pointedly, both Schopenhauer (1844/1966) and Freud (1905/1961) maintained that people, eager to regard themselves as civilized and reasonable, repress the unsettling knowledge that sexual urges prompt much of their behavior. Earlier, La Rochefoucauld (1678/1827), in his celebrated volume of aphorisms, repeatedly emphasized how amour-propre prompted

Address correspondence to Constantine Sedikides, School of Psychology, University of Southampton, Highfield Campus, Southampton S017 1BJ, England, United Kingdom; e-mail: cs2@soton.ac.uk. people to deceive both others and themselves. Even Nietzsche (1886/1972), that eloquent apologist for self-aggrandizement, warned that pride had the power to rewrite memory (Maxim 68, p. 72).

Ultimately, it fell to William James (1890/1950) to systematize such assorted observations and to posit a principle to unify them. In Chapter 10 of his Principles of Psychology, he noted that the "central part of the Self is felt" (p. 298) and that "self-complacency and self-dissatisfaction" (p. 305) are the primary emotions aroused by contemplating the constituents of selfhood. Furthermore, people's urgent concern with achieving tangible success and earning public acclaim ("social self-seeking") suggested to James that "each of us is animated by a direct feeling of regard for his [self]" (p. 308). James then defined this self as an object of consciousness-an empirical "me" comprised of ego-relevant interests, and not merely a metaphysical "I" providing some abstract principle of identity.

Over a century later, this empirical "me" has become a topic of extensive scientific research and theory, much of it pertaining to the key animating principle first identified by James: selfenhancement (Baumeister, 1998; J.D. Brown, 1998; Sedikides \& Gregg, 2003). Surprisingly, however, much recent philosophy of mind-despite delving in detail into the criteria for personal identity (Gallagher \& Shear, 1999; Parfit, 1984) and into the paradoxes of self-deception (Elster, 1986; Mele, 2001)—has had comparatively little to say about why the self, for all its notorious elusiveness, demands to be so positively evaluated (but see Kurzban \& Aktipis, 2007, for one recent attempt).

\section{A GASTRONOMIC ANALOGY}

Roughly speaking, self-enhancement involves taking a tendentiously favorable view of oneself. In what follows, we will try to further clarify the concept by drawing an extended (and perhaps far-fetched) analogy between it and a more familiar concept: eating. We do this because the term self-enhancement can refer to several phenomena that stand in need of careful distinction. Eating is a motivated activity in humans; one rooted in biology but regulated by culture. Precisely because 
eating manifests itself in various ways and at different levels, it can do analogical justice to the intricacies of self-enhancement.

\section{LEVELS OF SELF-ENHANCEMENT}

We propose that self-enhancement manifests itself at four levels: as an observed effect, an ongoing process, a personality trait, and an underlying motive. Consider now our gastronomic analogy. One can have finished eating, as attested by the presence of an empty plate. One can be in the process of eating- the activity by which that plate gets cleared of food. One can further be chronically well-fed from dining heartily on a regular basis. Finally, one can have an appetite for food-the desire that sustains eating. In all four cases, the common thread is the ingestion of food. In the case of self-enhancement, the corresponding common thread would be positive self-evaluation.

By way of illustration, consider the better-than-average effect (BTAE) - the tendency for people to rate themselves higher than others on desirable trait dimensions in contravention of statistical logic (Alicke \& Govorun, 2005). Such higher self-ratings, as an observed effect, ostensibly qualify as an instance of selfenhancement. Yet self-enhancement could also refer to the egorelevant mechanisms held to produce the BTAE: an ongoing process. Furthermore, if one were to manifest the BTAE habitually, then one would be displaying self-enhancement as a personality trait. Finally, if one genuinely wished to see oneself as superior, then this might be an underlying motive driving the BTAE.

This four-way conceptual partition is relevant for several reasons. First, self-enhancement, considered as either an observed effect or personality trait, need not entail self-enhancement as an ongoing process or underlying motive. In other words, a particular expression or manifestation of positive self-evaluation can admit of several alternative explanations, including nonmotivational ones. (In comparison, gluttony and hunger are not the only reasons people consume high-fat food or put on weight — food availability and physical inactivity also play a role.) Hence, care should be taken to not immediately identify phenomena of interest with their putative causes. Second, and conversely, self-enhancement can occur as a ongoing process or underlying motive without necessarily manifesting itself as an observed effect or personality trait. The motive to self-enhance, and the psychological activities it prompts, will sometimes fail to prompt positive self-evaluation. (In comparison, hunger does not always result in eating, as food may be unavailable, nor does eating always cause weight gain, such as in the case of hyperthyroidism.) Third - and more generally — given the distinctions between self-enhancement levels, one should take care not to equivocate between them simply because an umbrella term exists. Conceptual clarity is as crucial to the scientific enterprise as methodological rigor (Machado \& Silva, 2007).

As a case in point, consider the ongoing controversy over whether self-enhancement is adaptive or maladaptive- that is, whether self-enhancement helps or hinders the attainment of well-being, success, health, and amity (Chang, 2007; Sedikides, Gregg, \& Hart, 2007). We cannot do this complex controversy justice here. We merely note that much already hinges on how self-enhancement is defined and operationalized. For example, if self-enhancement is taken to mean rendering more positive judgments of oneself than of others, then outcomes are frequently favorable (Swann, Chang-Schneider, \& McClarty, 2007; Trzesniewski et al., 2006; but see Baumeister, Campbell, Krueger, \& Vohs, 2003), whereas if self-enhancement is taken to mean rendering more positive judgments of oneself than others render, then outcomes are often untoward (Colvin, Block, \& Funder, 1995; Paulhus, 1998; but see Bonanno, Rennicke, Dekel, \& Rosen, 2005). The debate is further complicated by the fact that a single operationalization of self-enhancement can be influenced by a variety of motives and, thus, can be coordinated with both positive and negative outcomes (Gramzow, Elliot, Asher, \& McGregor, 2003). Some careful attempts have been made to resolve these issues methodologically (Kwan, John, Kenny, Bond, \& Robins, 2004). However, for present purposes, we note that much relevant research conceives of self-enhancement as an observed effect or as a personality trait (Segerstrom \& Roach, 2007). As such, it necessarily encounters difficulties factoring out confounds with reality (e.g., does personally defined self-enhancement correlate with actual superiority and/or does socially defined self-enhancement correlate with actual inferiority?). If one instead conceives of self-enhancement as a psychological process driven by an underlying motive, then a more disquieting picture emerges (Dunning, Heath, \& Suls, 2004; Klein \& Cooper, 2007), as we discuss below.

\section{DIMENSIONS OF SELF-ENHANCEMENT}

Self-enhancement can be further characterized as varying along several bipolar dimensions. First, one can self-enhance either by self-advancing or self-protecting-that is, either by augmenting the positivity or diminishing the negativity of the selfconcept or self-regard (Arkin, 1981). (The gastronomic analogy would here be that one can eat to pleasure one's palate or to stave off starvation.) This classification is a subset of the more general distinction between approach and avoidance (Elliot \& Mapes, 2005). One empirical implication is that self-protection is a more urgent priority than self-advancement, given that, in general, "bad is stronger than good" (Baumeister, Bratslavsky, Finkenauer, \& Vohs, 2001). For example, the discrepancy between the self one currently is and the self one fears he or she might become predicts emotional states better than the discrepancy between the self one currently is and the self one would ideally like, or feels morally obliged, to be (Heppen \& Ogilvie, 2003). Individual differences also moderate which strategy people adopt: Those with higher self-esteem prioritize self-advancement, whereas those with lower self-esteem prioritize self- 
protection (Tice, 1991), in keeping with their corresponding tendencies towards risk-seeking or risk-aversion (Josephs, Larrick, Steele, \& Nisbett, 1992).

Second, one can self-enhance either publicly or privately. The former involves an element of favorable self-presentation (Leary \& Kowalski, 1990), whereas the latter is a more purely intrapsychic affair (Greenwald \& Breckler, 1985). (The gastronomic analogy here would be that one can eat either to satisfy hunger pangs or out of social politeness.) The distinction is empirically relevant because the presence of others sometimes potentiates self-enhancement (Leary, Tchividjian, \& Kraxberger, 1994) and sometimes inhibits it (Sedikides, Campbell, Reeder, \& Elliot, 1998). And although self-enhancement unquestionably occurs in private (J.D. Brown \& Gallagher, 1992), social reality may be introspectively introjected so that self-evaluation may always implicitly take place in comparison with imagined others (Klein, 1997).

Third, people differ in terms of which domains matter most to them (Crocker \& Wolfe, 2001). Self-enhancement occurs mainly in domains that do matter rather than in those that do not (Crocker, 2002; Sedikides, Gaertner, \& Toguchi, 2003). As William James (1890/1950) put it, "I, who for the time have staked my all on being a psychologist, am mortified if others know much more psychology than I. But I am contented to wallow in the grossest ignorance of Greek" (p. 310). (In comparison, people crave the foods they enjoy most.) Also relevant here are the orthogonal constructs of agency and communion (Paulhus \& John, 1998), because individual differences in their relative importance show distinctive correlates (Campbell, Rudich, \& Sedikides, 2002).

Finally, self-enhancement can be either candid or tactical (Sedikides \& Strube, 1997). That is, one can both seize an opportunity for overt and immediate self-advancement, or one can forgo it in favor of other activities liable to facilitate delayed selfenhancement. For example, one might tactically seek out diagnostic rather than flattering information about oneself (Trope, 1986) to remedy deficiencies or expand competencies (Pyszczynski, Greenberg, \& Goldenberg, 2003), thereby enabling one to engage in more justified and enduring self-enhancement in the future. (In comparison, working up an appetite increases subsequent enjoyment of food.) A reason to prefer tactical over candid self-enhancement is that other people generally dislike seeing the latter on display (Sedikides, Gregg, \& Hart, 2007). Indeed, narcissism can be characterized as involving an impulsive preference for candid self-enhancement (Vazire \& Funder, 2006), possibly because of a more pressing underlying motive to self-enhance (Sedikides \& Gregg, 2001).

\section{MANIFESTATIONS OF SELF-ENHANCEMENT}

Putting aside the above distinctions for a moment, in what ways do people self-enhance? The short answer is "many"; the self- enhancement "menu" contains an array of items, both classic dishes and subtle side-orders.

\section{Ostensible Effects}

A triad of positive illusions has been identified (Taylor \& Brown, 1988): People inflate their perceptions of themselves (e.g., the BTAE), exaggerate their level of control over events, and are overly optimistic about their future. Some examples of each follow: First, university students in the U.S. and Europe regard themselves as above-average drivers (Svenson, 1981), and even drivers hospitalized after causing accidents persist in believing they are no worse than regular drivers (Preston \& Harris, 1965); second, people perceive themselves to be in control of random tasks (e.g., dice throws) that irrelevantly resemble skill-based tasks (Langer, 1975) and see their actions to be influential even when they are immaterial (Jenkins \& Ward, 1965); and third, people interpret probability adverbs to mean higher values for personal positive outcomes and lower values for personal negative outcomes (Smits \& Hoorens, 2005), whereas smokers underestimate their risk of cancer relative to both nonsmokers and fellow smokers (Weinstein, Marcus, \& Moser, 2005). Moreover, across many parameters, these positive illusions replicate reliably and are resistant to revision (for inflation, see Alicke, Vredenburg, Hiatt, \& Govorun, 2001; for control, see FentonO'Creevy, Nicholson, Soane, \& Willman, 2003; for optimism, see Helweg-Larsen \& Shepperd, 2001). An ironic addendum is that most people consider themselves to be less prone to such illusions than others, even when explicitly told of their existence (Pronin, Gilovich, \& Ross, 2004).

A further signature of self-enhancement is the self-serving attributional bias. People claim credit for successes but renounce responsibility for failures: They attribute the former internally to the self but attribute the latter externally to others or to chance (Mezulis, Abramson, Hyde, \& Hankin, 2004). Kindred biases also exist for explanations for moral conduct (Baumeister, Stillwell, \& Wotman, 1990) and group behavior (Pettigrew, 2001).

\section{Alternative Explanations}

Do such ostensible effects reflect a motivated process of selfenhancement or something else? The question of whether cognitive processes can account for seemingly motivational effects is a perennial and vexatious one in social psychology (Kunda, 1990; Tetlock \& Levi, 1982), and it reemerges here (Alicke \& Govorun 2005; Chambers \& Windschitl, 2004).

To begin with, people regard themselves as above average on easy tasks like riding a bicycle but below average on difficult tasks like riding a unicycle (Kruger, 1999). This suggests that, when sizing themselves up against others, people egocentrically focus on how difficult or easy they would find a task and then tendentiously extrapolate to the comparison they make, but not necessarily in a self-enhancing way. In keeping with this in- 
terpretation, people's ratings of themselves relative to others correlate better with their ratings of themselves than of others (Epley \& Dunning, 2006). In addition, whenever any individual, not merely the self, is compared with a (nonnegative) collective, he or she comes off relatively favorably (Klar \& Giladi, 1997). Unsurprisingly then, when the comparison target is individuated, the BTAE effect dwindles (Alicke, Klotz, Breitenbecher, Yurak, \& Vredenburg, 1995).

Similar deflationary findings emerge for overoptimism. Here, event commonness is a key moderator: People consider frequently occurring positive events, like living past the age of 70, as being comparatively more likely to happen to themselves but consider rarely occurring positive events, like living past the age of 100 , as comparatively more likely to happen to others (Chambers, Windschitl, \& Suls, 2003). Egocentrism again seems like a viable explanation: For example, manipulations that shift attention from the self to the comparative target curtail overoptimism (Eiser, Pahl, \& Prins, 2001). One even wonders whether the more potent overoptimism effects observed for controllable events (Harris, 1996) and the greater self-inflation observed for controllable traits (Alicke, 1985)—both of which seemingly reflect a self-enhancing synergy between two positive illusions - might simply be due to controllable events and traits being more commonplace (Moore, 2007). As for the self-serving attributional bias, this might derive from legitimate expectations of success combined with misperception or misconstrual of contingencies (Miller \& Ross, 1975).

Nonetheless, although cognitive factors contribute, often substantially, to positive illusions, they do not wholly explain them. For example, self-inflation persists even in comparison with concrete others (Alicke et al., 1995), and event positivity explains variance in overoptimism above and beyond event commonness (Chambers et al., 2003). In addition, idiosyncratic domain and trait importance respectively moderate both the self-serving attributional bias (Campbell \& Sedikides, 1999) and the above-average effect (Sedikides, Gaertner, \& Vevea, $2007 \mathrm{~b}$ ), a pattern unlikely to be wholly explained by other confounds.

\section{Subtler Signs}

Self-enhancement manifests itself in less obvious ways too. In such cases, unconscious psychological processes are automatically recruited as a means of protecting and advancing selfregard. In other words, self-enhancement occurs more as an ongoing process than as an observed effect-in gastronomic terms, more like the act of eating itself than the (variously explainable) presence of an empty plate.

For example, several studies find evidence of egotistical distortions not only in the forecasting of future events, but also in the remembrance of things past. People preferentially forget negative feedback about themselves (Sanitioso \& Wlodarski, 2004), specifically in domains that matter to them (Sedikides \&
Green, 2000), even when that feedback is hypothetical (Green \& Sedikides, 2004; Sedikides \& Green, 2004). In addition, people preferentially and more quickly recall behaviors exemplifying traits deemed diagnostic of success (Sanitioso, Kunda, \& Fong, 1990), and they report such traits as being subjectively easier to recall (Sanitioso \& Niedenthal, 2006). People also remember performing more desirable concrete acts during a group discussion task than objective coders can later identify (Gosling, John, Craik, \& Robins, 1998). They also recall higher test scores than they actually received, with this self-enhancing memory bias increasing as the test becomes more temporally distant (Willard \& Gramzow, in press). Furthermore, judgments related to memory (e.g., hindsight biases) show self-serving distortions. Past failures are perceived as having been more inevitable and unforeseeable to the extent that one was invested in the possibility of success (Blank \& Nestler, 2006). Such memory biases vary positively with level of self-esteem (Tafarodi, Marshall, \& Milne, 2003).

Moreover, the somewhat elastic content of the self-concept gets stretched in a complimentary direction. For example, people define virtues in terms of the traits they possess and define vices in terms of the traits they lack (Dunning, Perie, \& Story, 1991), especially when their self-esteem is high (Beauregard \& Dunning, 2001). These definitions then prompt either more judgmental or generous evaluation of others, whichever casts the self in a better light (Alicke, LoSchiavo, Zerbst, \& Zhang, 1997). Indeed, people not only self-servingly compare themselves with others, but they also compare themselves with how they used to be: They construe their current and future selves as better than their past selves (Wilson \& Ross, 2001) and psychologically distance themselves more from previous negative episodes than from positive episodes (M. Ross \& Wilson, 2002).

\section{DYNAMICS OF SELF-ENHANCEMENT}

Consider again our gastronomic analogy. Suppose one wished definitively to establish that eating had motivational roots. Finding empty plates or observing people eat would provide circumstantial evidence for such a motivation. But more decisive evidence would come from starving or stuffing people and then observing their food-seeking preferences and behavior. Similarly, the dynamic operation of the self-enhancement motive is more clearly revealed by studies that challenge or affirm people's ego and then observe how they subsequently feel or act.

\section{Behavioral Self-Handicapping}

Although performing well matters to people, they sometimes act in ways that paradoxically hinder performance (Jones \& Berglas, 1978). They do this either to protect themselves against the shame of performing poorly (by manufacturing a convenient excuse: discounting) or to enhance themselves by succeeding 
despite adversity (and manufacturing grounds for conceit: augmenting; Rhodewalt, Morf, Hazlett, \& Fairfield, 1991). The discounting form of behavioral self-handicapping is liable to occur when one doubts one's capacity to perform due to shaky self-regard (Newman \& Wadas, 1997) or disbelief in the possibility of improvement (Ommundsen, 2001). High neuroticism and low conscientiousness also play a role (S.R. Ross, Canada, \& Rausch, 2002). Self-handicappers do manage to maintain positive self-views (McCrea \& Hirt, 2001) but only at the cost of impairing objective performance (Zuckerman \& Tsai, 2005). In addition, self-handicapping maintains competence-related esteem, even at the risk of incurring social censure (Rhodewalt \& Tragakis, 2002). Underscoring the motivational character of self-handicapping, people who bolster the self beforehand discount less (Arndt, Schimel, Greenberg, \& Pyszczynski, 2002). Behavioral self-handicapping is intriguing because it constitutes an empirical demonstration of the perplexing phenomenon of active self-deception (Giannetti, 2001).

\section{Partisan Processing}

Depending on whether people encounter congenial or uncongenial information (i.e., flattering or critical of their ego, implying promising or ominous prospects), they apply more lenient or stringent criteria while evaluating it and become correspondingly more likely to accept or reject it. Of congenial information, people ask "Can I believe it?", but of uncongenial information, they ask "Must I believe it?" (Dawson, Gilovich, \& Regan, 2007). For example, people consider personality feedback to be less accurate (Ditto \& Boardman, 1995) and consider scientific research to be less credible (Kunda, 1987) if it implies they are susceptible to disease. In addition, they also think harder about any inauspicious test results that they receive and will spend longer considering them, are more inclined to check them, and are more skeptical of them (Ditto \& Lopez, 1992); however, they do not react the same way to similar test results received by others (Ditto, Munro, Apanovitch, Scepansky, Lockhart, 2003). In addition, when research impugns the reputation of groups with which people identify, they pick out statistical weaknesses of that research (Doosje, Spears, \& Koomen, 1995). Such dynamics may partly underlie classic biased assimilation effects (Lord, Ross, \& Lepper, 1979), although biased scanning (Greenwald, 1969) and wishful perception (Balcetis \& Dunning, 2006) may also play a role.

\section{Social Comparison Processes}

The dynamics of self-enhancement extend into interpersonal life, in which involuntary social comparisons prompt self-regulatory strategies. According to self-evaluation maintenance (SEM) theory (Tesser, 1988), three factors are critical: one's performance in a domain, the personal relevance of that domain, and one's relationship to a target. First, when targets are close rather than distant, comparisons are more likely and are of greater consequence when they occur. Second, when a domain is relevant, comparison (or contrast) occurs, a better performance from another individual prompts self-derogation (e.g., humiliation), whereas a worse performance from another individual prompts self-enhancement (e.g., triumph). Third, when a domain is irrelevant, reflection (or assimilation) occurs, a worse performance from another individual prompts self-enhancement (e.g., vicarious pride), whereas a better performance from another individual prompts self-derogation (e.g., guilty shame).

Indeed, people have less favorable perceptions of targets' performance in ego-relevant domains when those targets are close rather than distant (Tesser \& Campbell, 1982). The aversive nature of these perceptions is attested to by the higher levels of accompanying physiological arousal (Achee, Tesser, \& Pilkington, 1994). To escape or forestall such negative feelings, people resort to several strategies including adjusting their perceptions of task relevance (Tesser \& Paulhus, 1983); choosing friends who, despite being roughly matched in level and type of ability, are somewhat less able in ego-relevant domains and are somewhat more able in ego-irrelevant domains (Tesser, Campbell, \& Smith, 1984); and acting so as to hinder close others' performance in ego-relevant domains (Pemberton \& Sedikides, 2001). Comparable effects are observed in married couples, with partners striving to complement rather than mimic each other's strengths (Beach, Whitaker, Jones, \& Tesser, 2001). However, matters are further complicated by the fact that partners empathize with and wish to accommodate each other's reflection and comparison processes (Pilkington, Tesser, \& Stephens, 1991) — a greater responsiveness to a partner's SEM needs than to one's own predicts positive social interactions (Mendolia, Beach, \& Tesser, 1996).

SEM theory focuses on the consequences of involuntary social comparisons, but people also have some latitude in terms of which target they compare with and in how they construe that target. In particular, although people generally compare themselves with similar or slightly superior others (Gruder, 1971), there are occasions on which they are disposed to compare themselves with inferior others (Wills, 1981)_for example, to boost their sense of optimism and control by contrast with lessfortunate individuals (Wood, Taylor, \& Lictman, 1985). However, assimilation as well as contrast effects can occur (Mussweiler, 2003), meaning that downward comparisons can be dispiriting (Wheeler \& Miyake, 1992) and that upward comparisons inspiring (Collins, 2000). Indeed, if a target's skill or success are regarded as attainable (Lockwood \& Kunda, 1997), upward comparisons facilitate self-enhancement via expectations for self-improvement. However, attempting to defend against an ego threat can bring out prejudices that would otherwise remain dormant. For example, a threat to intelligence or personal insult induce more stereotypical and less favorable attitudes towards gays, Blacks, and women (Fein \& Spencer, 1997; Sinclair \& Kunda, 1999, 2000) and lead to the automatic activation of such stereotypes and attitudes (Spencer, Fein, 
Wolfe, Fong, \& Dunn, 1998). However, such ungenerous construals of social targets can be undone by the manipulations discussed in the following section (Fein \& Spencer, 1997).

\section{Affirmations of Self}

Although the dynamics of self-enhancement discussed so far in principle encompass both self-protection and self-advancement, the emphasis has squarely been on dealing with ego threat. In contrast, self-affirmation (SA) theory focuses on ways of preemptively propping up the ego, with a view to lessening subsequent defensiveness (Sherman \& Cohen, 2006). (In terms of our gastronomic analogy - instead of depriving people of food to explore the perturbing impact of hunger, one instead fills people's bellies, to explore the protective impact of satiety.) The canonical manipulation involves having participants first report and then elaborate on a value or domain that they personally regard as important. Such a manipulation then reduces or eliminates a range of typical self-protective responses, which are itemized below. This effect suggests that a common psychic currency underlies various self-enhancement dynamics (Tesser, 2000). SA theory labels this underlying currency as self-integrity and defines it as "moral and adaptive adequacy." Still, given that it is claimed to involve at least two positive illusions (selfpositivity and perceived control), it can be equated, for our purposes, with something like positive self-regard.

SA effects were first empirically demonstrated in relation to cognitive dissonance phenomena (Harmon-Jones \& Mills, 1999). SA undermined their emergence (Steele \& Liu, 1983) and thereby indirectly implicating the ego in their genesis (Thibodeau \& Aronson, 1992). For example, science students who wore an identity-reinforcing lab coat no longer rationalized a difficult choice between two closely matched alternatives by augmenting their relative preference for the alternative they chose (Steele, Hopp, \& Gonzales, 1986; cited in Steele, 1988).

SA lessens bias. For example, it decreases the tendency for students to exaggerate their current academic performance (Gramzow \& Willard, 2006). It also alleviates the partisan processing of ambiguous messages in the direction of preexisting opinions and eliminates preferences for those who share one's views (Cohen, Aronson, \& Steele, 2000). Moreover, by reducing ideological entrenchment, it facilitates the making of concession crucial to the success of politically charged negotiations (Cohen et al., 2007). Such effects are mediated by increased attention to the central merits of arguments that opponents might advocate (Correll, Spencer, \& Zanna, 2004). In addition, although close relationships are sometimes characterized by competitive dynamics described by SEM theory, they also generally serve as a potent $\mathrm{SA}$ resource-one that opens people up to receiving critical information (Kumashiro \& Sedikides, 2005) and restores positive illusions (Martz et al., 1998).

Furthermore, SA makes people less reluctant to take on board potentially disquieting data about their health (Sherman, Nel- son, \& Steele, 2000), undoing standard biases (Reed \& Aspinwall, 1998). Moreover, SA seemingly provides not only a sustained impetus to health-promoting attitudes and actions (Harris \& Napper, 2005) but also concrete health benefits, in terms of both coping with stress and reducing symptoms (Creswell, Lam, et al., 2007; Creswell, Welch, et al., 2005). Finally, SA has positive implications for social comparisons and behavior. It wards off SEM concerns, making people less likely to sabotage the performance of close others in ego-relevant domains; people spontaneously use SA to cope with SEM threats (Tesser, Crepaz, Collins, Cornell, \& Beach, 2000). SA also acts as a prophylactic against derogatory social comparison. For example, participants led to believe that their intelligence was below average were normally prompted to bolster their egos by choosing to listen to an incompetent interviewee as opposed to competent one; however, an intervening SA manipulation symmetrically reverses this effect (Spencer, Fein, \& Lomore, 2001).

The above might be taken to imply that $\mathrm{SA}$ invariably yields edifying outcomes, which is not true. First, if the affirmation is in the same domain as the outcome rather than another, SA backfires (Stone \& Cooper, 2003). Second, if people affirm their rectitude or objectivity, then they become subsequently more likely to take ethical liberties (B.R. Brown, 2000) or engage in gender discrimination (Uhlmann, 2007). Third, if an ostensible self-enhancement effect is driven by an amotivated process (e.g., a cognitive bias in memory), SA has little impact on the magnitude of the bias (Gramzow \& Willard, 2006).

\section{PRIMACY OF SELF-ENHANCEMENT}

We have seen that self-enhancement emerges in a variety of guises, often exerting potent effects. The question frequently arises of just how primary self-enhancement is. Does it enjoy pride of place relative to other psychological effects, activities, traits, or motives? Unfortunately, questions of global primacy are notoriously difficult to settle (Ortony \& Turner, 1990), and initial assertions often require subsequent gentle qualification in the light of evidence and criticism (Solomon, Greenberg, \& Pyszczynski, 1997). Hence, instead of taking a position on this controversial issue, we identity two areas of relevant research, summarize key findings, and leave readers to draw their own conclusions.

By way of orientation, suppose one were to enquire into the primacy of eating in human behavior. What issues might be relevant? First, one could explore whether and to what extent people's eating was unconditional versus contingent. Would other factors (e.g., setting, appetite) moderate its expression, or would other imperatives (e.g., drinking, staying slim) eclipse it? Second, one could explore whether and to what extent eating is universal or culture specific. Would eating, or specific dining practices (e.g., fast food, gourmet dining), characterize all cultures or only some? Below, we explore two analogous issues with regard to self-enhancement. 


\section{Constraints on Self-Enhancement}

According to Demosthenes (384-322 BCE), the Greek orator of antiquity, "Nothing is so easy as to deceive oneself; for what we wish, we readily believe." But this is plain wrong-blatant selfdeception is very difficult. That is, people cannot self-enhance willy-nilly; they must have sufficient grounds in their own eyes for doing so. Unfortunately, such grounds are not automatically forthcoming. To be reasonable, as opposed to delusional, is to acknowledge that there are limits to what one can believe about oneself and that reality informs us as to what these limits are. Consequently, reason is not, as Hume (1738/1951) famously put, "only the slave of the passions" (p. 415), but it is also sometimes their master-albeit only partially and perhaps reluctantly.

Several lines of evidence bear out the view that self-enhancement occurs within the constraints imposed by rationality and reality. For example, when extraverts and introverts are led to believe that either extraversion or introversion predicts success, they duly rate themselves higher than they otherwise would on adjectives associated with the successful trait; but still, their ratings remain more shaped by their preexisting personalities than by the manipulated desirability of the traits (Sanitioso et al., 1990). In addition, the BTAE occurs on ambiguously defined traits (e.g., idealistic) rather than well-defined traits (e.g., punctual) — even when the ambiguity involved is created or eliminated experimentally (Dunning, Meyerowitz, \& Holzberg, 1989). Furthermore, ambiguous (rather than well-defined) comparison targets facilitate self-enhancing social comparisons (Stapel \& Schwinghammer, 2004). In sum, positive self-evaluations reflect not only what people want to believe, but also what they can believe. (Gastronomically speaking, one can only indulge one's appetite to the extent one can afford to.)

Other findings illustrate indirectly how self-enhancement is bounded by cognitive constraints. People evaluate their own work less positively if they know that they will subsequently have to defend and justify their evaluation before an audience. Being held accountable in this way (Lerner \& Tetlock, 1999) leads people to anticipate being assessed as identifiable individuals (Sedikides, Herbst, Hardin, \& Dardis, 2002), which in turn prompts them to consider areas of possible weakness (Sedikides \& Herbst, 2002). Similar manipulations attenuate the above-average effect in domains such as driving ability (McKenna \& Myers, 1997). Accountability may also explain self-effacement among (relatively knowledgeable) friends than among (more ignorant) strangers (Tice, Butler, Muraven, \& Stillwell, 1995). Self-evaluations also become less positive, and self-concepts become less certain, when people generate and concretize possible reasons for why they might or might not possess particular personality traits, an activity we dub explanatory introspection (Sedikides, Horton, \& Gregg, 2007). In both cases, the mechanism curtailing self-enhancement involves drawing people's attention to demerits they are usually content to overlook.
Cognitive constraints are apparent in another way: When reason is impaired, either by situational or dispositional factors, self-enhancement is let loose. When people are put under cognitive load or are distracted by affect-laden stimuli, they become faster at endorsing and slower at denying positive traits relative to negative traits, and they also endorse more of the former than the latter (Paulhus, Graf, \& Van Selst, 1989; Paulhus \& Levitt, 1987). In addition, people of lower ability in various domains, who lack the metacognitive capacity to appraise themselves validly, estimate their abilities to be considerably in excess of what they are (Kruger \& Dunning, 1999).

Yet, when time to think is available, the self-assessment motive (Trope, 1986) often prevails. The key claim here is that the pursuit of accurate information about the self matters in itself whether or not this information is positive or negative, because having an accurate self-view affords a sense of uncertainty reduction. Indeed, people prefer tasks that provide the most diagnostic information about their abilities in domains of which they are most uncertain (Trope, 1979), regardless of whether tasks diagnose success or failure (Trope, 1980). They also expend more effort and persist longer completing such diagnostic tasks (Trope, 1982; Trope \& Ben-Yair, 1982). Admittedly, such impartial curiosity is not always observed: On a neutral selfreflective task, for example, people choose to ask themselves more diagnostic questions about positive rather than negative traits in important domains and about traits they hold in high rather than low certainty (Sedikides, 1993).

Nonetheless, the truth about oneself clearly matters. So does this undermine the primacy of the self-enhancement motive? Not necessarily. Consider our gastronomic analogy again. First, the fact that people pragmatically restrict their eating within the constraints imposed by food availability does not demote hunger to the status of a secondary drive. Second, people sometimes voluntarily restrict their eating to work up a better appetite for later. That is, self-assessment, by subserving subsequent selfimprovement, can tactically facilitate eventual self-enhancement (Sedikides \& Gregg, 2003). Thus, self-assessment may not reflect an interest in self-knowledge for its own sake, but rather a form of prudent and adaptive self-control (Tangney, Baumeister, \& Boone, 2004) in which immediate ego gratification is discounted relative to delayed ego gratification (Metcalfe \& Mischel, 1999).

What factors moderate whether people will self-assess versus self-enhance? We have already seen how SA increases openness to critical or inauspicious information (Sherman \& Cohen, 2006). Positive mood exerts similar effects (Raghunathan \& Trope, 2002). It increases interest in negative or liability-focused feedback, and people spontaneously prepare for such feedback by reviewing past successes (Trope \& Pomerantz, 1998). Is self-enhancement therefore reducible to mood regulation (Tesser, 2000)? There are two reasons not to think so. First, self-enhancement has an intentional object (Searle, 1983) - it is about the self, whereas mood is not about anything 
in particular. Second, mood does not mediate SA effects (Sherman \& Cohen, 2006). Nonetheless, positive mood certainly does have an energizing and restorative effect (Tice, Baumeister, Shmueli, \& Muraven, 2007) and may account for many of the functional benefits of self-enhancement (Roese \& Olson, 2007).

Another factor moderating whether people self-assess or selfenhance is the perceived modifiability of the ability under consideration. In particular, when a trait is seen as modifiable, people are less affectively disturbed by critical feedback and are more interested in receiving it as well (Dauenheimer, Stahlberg, Spreeman, \& Sedikides, 2002; Green, Pinter, \& Sedikides, 2005). They are also more likely to make internal attributions of failure (Duval \& Silvia, 2002). In general, when something can still be changed, self-assessing realism tends to predominate, whereas when something is a fait accompli, self-enhancing rationalizations take over (Roese \& Olson, 2007).

Finally, alongside self-enhancement and self-assessment (and its close cousin, self-improvement), a further self-motive has been postulated: self-verification (Swann, Rentrow, \& Guinn, 2003) The key claim here is that identity matters in itself whether or not it is positive or realistic, because having a coherent self-view affords a satisfying sense of prediction and control in the interpersonal sphere. Moreover, some behavioral evidence provocatively suggests that people are keener to selfverify rather than self-enhance. For example, when given the choice, people with negative self-views (e.g., depressives) opt to interact with people who view them negatively as opposed to positively and opt to read feedback that portrays them negatively as opposed to positively (Giesler, Josephs, \& Swann, 1996). Such dynamics are counterintuitive and are worthy of empirical attention as they are liable to stabilize often needlessly negative self-views. However, it remains a moot point whether such choices reflect the operation of a corresponding motive. An alternative interpretation is that people with negative self-views seek negative feedback, not because they want it to reinforce their strangely cherished negative identity, but because they do not regard themselves as rationally entitled to believe positive feedback, even though they would dearly like to (Gregg, in press).

\section{Universality of Self-Enhancement}

Culture is another apparently potent moderator of self-enhancement. It has been claimed that Easterners (e.g., Chinese, Japanese) self-enhance less overall than Westerners (e.g., Americans, Europeans) and that-in some senses and waysthey do not self-enhance at all (Heine \& Hamamura, 2007; Heine, Lehman, Markus, \& Kitayama, 1999). This alleged difference in mental make-up is one of many attributed to the divergent cultural traditions characterizing the West and East (Heine et al., 1999; Markus \& Kitayama, 1991). The issue has evoked considerable controversy (J.D. Brown \& Kobayashi, 2002; Heine, 2003, 2005; Sedikides et al., 2003). Philosophi- cally speaking, the issue recalls the perennial debate between relativism and constructivism on the one hand and objectivism and realism on the other (Rorty, 1979; Searle, 1997). Is selfenhancement merely a contingent human practice that emerges only occasionally, or is it a necessary human attribute that is permanently present? We believe that the answer to the question, and the correct interpretation of findings to date, turns crucially on the level of self-enhancement one has in mind.

At the level of observed effects or personality traits, there is indeed some evidence that Easterners self-enhance less than Westerners. For example, Easterners spontaneously describe themselves in more negative terms than Westerners (Kanagawa, Cross, \& Markus, 2001), make self-deprecatory social comparisons (Takata, 1987), and show a reduced or reversed selfserving attributional bias (Hamamura \& Heine, 2007). That said, it has nonetheless been meta-analytically documented that, in domains which Easterners and Westerners each regard as idiosyncratically or normatively important, an above-average bias emerges for everyone (Sedikides, Gaertner, \& Vevea, 2005, 2007a, 2007b). This result squares with the view that, although the domain of self-enhancement might vary across culture, the phenomenon of self-enhancement is itself invariant (Sedikides et al., 2003).

However, let us play devil's advocate and imagine that Easterners never self-enhanced at the level of an effect or a trait. Arguably, such a state of affairs would still not undermine the claim that the self-enhancement operated universally at the level of a process or a motive. The reason is that, as stated above, self-enhancement can be tactical as well as candid (Sedikides \& Strube, 1997). Hence, consistent null effects might simply reflect consistently tactical self-enhancement. Of course, Easterners do candidly self-enhance in important domains by overtly self-inflating (Sedikides et al., 2007a, 2007b). In addition, the same defensive dynamics in response to ego threat occur in the East as in the West (Heine, Niiya, \& Harihara, 2002), although further decisive research along these lines is needed. Nonetheless, the overall character of oriental and occidental selfenhancement may differ-a point on which partisans on both sides of the issue seem to concur. When taking into account such etic phenomena as the imperative to maintain face in Eastern cultures (Hamamura \& Heine, 2007) and recalling the four key dimensions of self-enhancement outlined earlier, we would postulate that, relative to Westerners, Easterners self-enhance not only more tactically than candidly (but always candidly in domains of importance), but that they do so by self-protecting more than by self-advancing (Hamamura \& Heine, 2007) and more in private than in public (Crittenden, 1991).

Once again, the gastronomic analogy comes to our aid in clarifying matters. Cross-cultural differences in eating habits are evident. Perhaps conveniently for our analogy, the stereotypical Westerner consumes generous portions of burgers, whereas the stereotypical Easterner consumes more modest portions of sushi. However, the underlying motive-hunger- 
remains universal, even as its expression varies. To continue the analogy, one would still expect both Easterners and Westerners to greedily devour their favorite foods. In addition, we would expect Westerners, relative to Easterners, to prioritize palatepleasuring in public.

Do any other findings suggest that self-enhancement is a true human universal phenomenon rather than a culturally specific phenomenon? Indeed, there are several that do so. First, although the degree of overt self-enhancement may differ between cultures, trait self-enhancement (e.g., self-esteem) nonetheless shows the same pattern of correlations with other personality traits across all cultures (Schmitt \& Allik, 2005). Moreover, average levels of self-esteem invariably lie above theoretical scale midpoint. Second, genes account for substantial variance in levels of self-esteem (Neiss, Sedikides, \& Stevenson, 2006). This suggests that cultural variations, at least in those environments so far studied, do not wholly explain trait self-enhancement. Third, implicit self-esteem, reflected in the automatic and involuntary positive evaluation of stimuli that denote or connote the self (e.g., one's name, personal pronouns), characterizes Easterners and Westerners equally (Yamaguchi et al., 2007). This implies that, at a primitive level of mental operation beyond the reach of social desirability, the pleasant scent of self consistently perfumes nearby objects. Fourth, several specific sites in the brain have been identified as subserving self-enhancement dynamics (Heatherton, Krendl, Macrae, \& Kelley, 2007). Thus, the ego seems to have a locatable physical substratum. Fifth, the link between selfenhancement and health has been observed not only in the West (Taylor, Lerner, Sherman, Sage, \& McDowell, 2003) but also in the East (Gaertner, Sedikides, \& Chang, in press). Finally, researchers have constructed several plausible models, some evidentially supported, implicating self-enhancement, in one way or another, as a useful evolutionary adaptation. These include self-enhancement as an energizing principle (Sedikides \& Skowronski, 2000), as an index of social value (Leary \& Baumeister, 2000), or as a defense against mortality (Pyszczynski, Greenberg, Arndt, \& Schimel, 2004). For all these reasons, self-enhancement can be considered a cornerstone of human psychology.

\section{EPILOGUE}

La Rochefoucauld (1678/1827) noted that "Whatever discoveries have been made in the land of self-love, many territories remain to be discovered." Thanks to the recent growth of empirical psychology, the terra incognita of the ego is beginning to be mapped by an array of specialized cartographers. Nonetheless, La Rochefoucauld's remark remains as apt today as it was in the 17th century. We hope (at the risk of mixing metaphors!) that our review of the phenomenon of self-enhancement will have both satisfied our readers' appetite for current scientific wisdom and given them food for further thought.

\section{REFERENCES}

Achee, J., Tesser, A., \& Pilkington, C. (1994). Social perception: A test of the role of arousal in self-evaluation maintenance processes. European Journal of Social Psychology, 24, 147-159.

Alicke, M.D. (1985). Global self-evaluation as determined by the desirability and controllability of trait adjectives. Journal of Personality and Social Psychology, 49, 1621-1630.

Alicke, M.D., \& Govorun, O. (2005). The better-than-average effect. In M.D. Alicke, D.A. Dunning, \& J.I. Krueger (Eds.), Studies in self and identity (pp. 85-106). New York: Psychology Press.

Alicke, M.D., Klotz, M.L., Breitenbecher, D.L., Yurak, T.J., \& Vredenburg, D.S. (1995). Personal contact, individuation, and the better-than-average effect. Journal of Personality and Social Psychology, 68, 804-825.

Alicke, M.D., LoSchiavo, F.M., Zerbst, J., \& Zhang, S. (1997). The person who out-performs me is a genius: Maintaining perceived competence in upward social comparison. Journal of Personality and Social Psychology, 73, 781-789.

Alicke, M.D., Vredenburg, D.S., Hiatt, M., \& Govorun, O. (2001). The better than myself effect. Motivation and Emotion, 25, 7-22.

Arkin, R.M. (1981). Self-presentation styles. In J. Tedeschi (Ed.), Impression management theory and research (pp. 311-333). New York: Academic Press.

Arndt, J., Schimel, J., Greenberg, J., \& Pyszczynski, T. (2002). The intrinsic self and defensiveness: Evidence that activating the intrinsic self reduces self-handicapping and conformity. Personality and Social Psychology Bulletin, 28, 671-683.

Balcetis, E., \& Dunning, D. (2006). See what you want to see: Motivational influences on visual perception. Journal of Personality and Social Psychology, 91, 612-625.

Baumeister, R.F. (1998). The self. In D.T. Gilbert, S.T. Fiske, \& G. Lindzey (Eds.), Handbook of social psychology (4th ed., pp. 680740). New York: McGraw-Hill.

Baumeister, R.F., Bratslavsky, E., Finkenauer, C., \& Vohs, K.D. (2001). Bad is stronger than good. Review of General Psychology, $5,323-370$.

Baumeister, R.F., Campbell, J.D., Krueger, J.I., \& Vohs, K.D. (2003). Does high self-esteem cause better performance, interpersonal success, happiness, or healthier lifestyles? Psychological Science in the Public Interest, 4, 1-44.

Baumeister, R.F., Stillwell, A., \& Wotman, S.R. (1990). Victim and perpetrator accounts of interpersonal conflict: Autobiographical narratives about anger. Journal of Personality and Social Psychology, 59, 994-1005.

Beach, S.R.H., Whitaker, D.J., Jones, D.J., \& Tesser, A. (2001). When does performance feedback prompt complementarity in romantic relationships? Personal Relationships, 8, 231-248.

Beauregard, K.S., \& Dunning, D. (2001). Defining self-worth: Trait self-esteem moderates the use of self-serving trait definitions in social judgment. Motivation and Emotion, 25, 135-162.

Bentham, J. (1982). An introduction to the principles of morals and legislation (J.H. Burns \& H.L.A. Harts, Eds.). London: Methuem. (Original work published 1789)

Blank, H., \& Nestler, S. (2006). Perceiving events as both inevitable and unforeseeable in hindsight: The Leipzig candidacy for the Olympics. British Journal of Social Psychology, 45, 149-160.

Bonanno, G.A., Rennicke, C., Dekel, S., \& Rosen, J. (2005). Selfenhancement among high-exposure survivors of the September 11th terrorist attack: Resilience or social maladjustment? Journal of Personality and Social Psychology, 88, 984-988. 
Brown, B.R. (2000). When moral entitlement leads to immoral acts. Unpublished doctoral dissertation, Stanford University, Stanford, CA.

Brown, J.D. (1998). The self. New York: McGraw-Hill.

Brown, J.D., \& Gallagher, F.M. (1992). Coming to terms with failure: Private self-enhancement and public self-effacement. Journal of Experimental Social Psychology, 28, 3-22.

Brown, J.D., \& Kobayashi, C. (2002). Self-enhancement in Japan and America. Asian Journal of Social Psychology, 5, 145167.

Campbell, W.K., Rudich, E., \& Sedikides, C. (2002). Narcissism, selfesteem, and the positivity of self-views: Two portraits of self-love. Personality and Social Psychology Bulletin, 28, 358-368.

Campbell, W.K., \& Sedikides, C. (1999). Self-threat magnifies the selfserving bias: A meta-analytic integration. Review of General Psychology, 3, 23-43.

Chambers, J.R., \& Windschitl, P.D. (2004). Biases in social comparative judgments: The role of nonmotivated factors in above-average and comparative-optimism effects. Psychological Bulletin, 130, 813-838.

Chambers, J.R., Windschitl, P.D., \& Suls, J. (2003). Egocentrism, event frequency, and comparative optimism: When what happens frequently is more likely to happen to me. Personality and Social Psychology Bulletin, 29, 1343-1356.

Chang, E.C. (Ed.). (2007). Self-criticism and self-enhancement: Theory, research, and clinical implications. Washington, DC: American Psychological Association.

Cohen, G.L., Aronson, J., \& Steele, C.M. (2000). When beliefs yield to evidence: Reducing biased evaluation by affirming the self. Personality and Social Psychology Bulletin, 26, 1151-1164.

Cohen, G.L., Sherman, D.K., Bastardi, A., McGoey, M., Hsu, A., \& Ross, L. (2007). Bridging the partisan divide: Self-affirmation reduces ideological closed-mindedness and inflexibility in negotiation. Journal of Personality and Social Psychology, 93, 415430.

Collins, R.L. (2000). Among the better ones: Upward assimilation in social comparison. In J. Suls \& L. Wheeler (Eds.), Handbook of social comparison (pp. 159-172). New York: Kluwer Academic/ Plenum.

Colvin, C.R., Block, J., \& Funder, D.C. (1995). Overly positive selfevaluations and personality: Negative implications for mental health. Journal of Personality and Social Psychology, 68, 11521162.

Correll, J., Spencer, S.J., \& Zanna, M.P. (2004). An affirmed self and an open mind: Self-affirmation and sensitivity to argument strength. Journal of Experimental Social Psychology, 40, 350-356.

Creswell, J.D., Lam, S., Stanton, A.L., Taylor, S.E., Bower, J.E., \& Sherman, D.K. (2007). Does self-affirmation, cognitive processing, or discovery of meaning explain cancer-related health benefits of expressive writing? Personality and Social Psychology Bulletin, 33, 238-250.

Creswell, J.D., Welch, W., Taylor, S.E., Sherman, D.K., Gruenewald, T., \& Mann, T. (2005). Affirmation of personal values buffers neuroendocrine and psychological stress responses. Psychological Science, 16, 846-851.

Crittenden, K.S. (1991). Self-effacement or feminine modesty? Attributional patterns of women university students in Taiwan. Gender and Society, 5, 98-117.

Crocker, J. (2002). Contingencies of self-worth: Implications for selfregulation and psychological vulnerability. Self and Identity, 1, $143-149$.
Crocker, J., \& Wolfe, C.T. (2001). Contingencies of self-worth. Psychological Review, 108, 593-623.

Dauenheimer, D.G., Stahlberg, D., Spreeman, S., \& Sedikides, C. (2002). Self-enhancement, self-assessment, or self-verification? The intricate role of trait modifiability in the self-evaluation process. Revue Internationale De Psychologie Sociale, 15, 89112.

Dawson, E., Gilovich, T., \& Regan, D. (2007). Motivated reasoning and susceptibility to the "Cell A" bias. Manuscript submitted for publication.

De Witt, N.W. (1973). Epicurus and his philosophy. Westport, CT: Greenwood Publishing Group.

Ditto, P.H., \& Boardman, A.F. (1995). Perceived accuracy of favorable and unfavorable psychological feedback. Basic and Applied Social Psychology, 16, 137-157.

Ditto, P.H., \& Lopez, D.F. (1992). Motivated skepticism: Use of differential decision criteria for preferred and non-preferred conclusions. Journal of Personality and Social Psychology, 63, $568-584$.

Ditto, P.H., Munro, G.D., Apanovitch, A.M., Scepansky, J.A., \& Lockhart, L.K. (2003). Spontaneous skepticism: The interplay of motivation and expectation in responses to favorable and unfavorable medical diagnoses. Personality and Social Psychology Bulletin, 29, 1120-1132.

Doosje, B., Spears, R., \& Koomen, W. (1995). When bad isn't all bad: The strategic use of sample information in generalization and stereotyping. Journal of Personality and Social Psychology, 69, 642-655.

Dunning, D., Heath, C., \& Suls, J. (2004). Flawed selfassessment: Implications for health, education, and the workplace. Psychological Science in the Public Interest, 5, 69106.

Dunning, D., Meyerowitz, J.A., \& Holzberg, A.D. (1989). Ambiguity and self-evaluation: The role of idiosyncratic trait definitions in self-serving assessments of ability. Journal of Personality and Social Psychology, 57, 1082-1090.

Dunning, D., Perie, M., \& Story, A.L. (1991). Self-serving prototypes of social categories. Journal of Personality and Social Psychology, 61, 957-968.

Duval, T.S., \& Silvia, P.J. (2002). Self-awareness, probability of improvement, and the self-serving bias. Journal of Personality and Social Psychology, 82, 49-61.

Eiser, J.R., Pahl, S., \& Prins, Y.R.A. (2001). Optimism, pessimism, and the direction of self-other comparisons. Journal of Experimental Social Psychology, 37, 77-84.

Elliot, A.J., \& Mapes, R.R. (2005). Approach-avoidance motivation and self-concept evaluation. In A. Tesser, J. Wood, \& D. Stapel (Eds.), On building, defending, and regulating the self: A psychological perspective (pp. 171-196). Washington, DC: Psychological Press.

Elster, J. (Ed.). (1986). The multiple self. Cambridge, United Kingdom: Cambridge University Press.

Epley, N., \& Dunning, D. (2006). The mixed blessings of self-knowledge in behavioral prediction: Enhanced discrimination but exacerbated bias. Personality and Social Psychology Bulletin, 32, 641-655.

Fein, S., \& Spencer, S.J. (1997). Prejudice as self-image maintenance: Affirming the self through derogating others. Journal of Personality and Social Psychology, 73, 31-44.

Fenton-O'Creevy, M., Nicholson, N., Soane, E., \& Willman, P. (2003). Trading on illusions: Unrealistic perceptions of control and 
trading performance. Journal of Occupational and Organisational Psychology, 76, 53-68.

Freud, S. (1961). Three essays on the theory of sexuality. In J. Strachey (Ed. and Trans.), The standard edition of the complete psychological works of Sigmund Freud (Vol. 19, pp. 3-66). London: Hogarth Press. (Original work published 1905)

Gaertner, L., Sedikides, C., \& Chang, K. (in press). On pancultural self-enhancement: Well-adjusted Taiwanese self-enhance on personally-valued traits. Journal of Cross-Cultural Psychology.

Gallagher, S., \& Shear, J. (1999). Models of the self. Exeter, United Kingdom: Imprint Academic.

Giannetti, E. (2001). Lies we live by: The art of self-deception. London: Bloomsbury.

Giesler, R.B., Josephs, R.A., \& Swann, W.B., Jr. (1996). Self-verification in clinical depression. Journal of Abnormal Psychology, 105, 358-368.

Gosling, S.D., John, O.P., Craik, K.H., \& Robins, R.W. (1998). Do people know how they behave? Self-reported act frequencies compared with on-line codings by observers. Journal of Personality and Social Psychology, 74, 1337-1349.

Gramzow, R.H., Elliot, A.J., Asher, E., \& McGregor, H. (2003). Selfevaluation bias and academic performance: Some ways and some reasons why. Journal of Research in Personality, 37, 41-61.

Gramzow, R.H., \& Willard, G. (2006). Exaggerating current and past performance: Motivated self-enhancement versus reconstructive memory. Personality and Social Psychology Bulletin, 32, 11141125.

Green, J.D., Pinter, B., \& Sedikides, C. (2005). Mnemic neglect and self-threat: Trait modifiability moderates self-protection. European Journal of Social Psychology, 35, 225-235.

Green, J.A., \& Sedikides, C. (2004). Retrieval selectivity in the processing of self-referent information: Testing the boundaries of self-protection. Self and Identity, 3, 69-80.

Greenwald, A.G. (1969). The open-mindedness of the counterattitudinal role player. Journal of Experimental Social Psychology, 5, 375-388.

Greenwald, A.G., \& Breckler, S.J. (1985). To whom is the self presented? In B.E. Schlenker (Ed.), The self and social life (pp. 126145). New York: McGraw-Hill.

Gregg, A.P. (in press). Is identity per se irrelevant? A contrarian view of self-verification effects. Anxiety and Depression.

Gruder, C.L. (1971). Determinants of social comparison choices. Journal of Experimental Social Psychology, 1, 473-489.

Hamamura, T., \& Heine, S.J. (2007). Self-enhancement, self-improvement, and face among Japanese. In E.C. Chang (Ed.), Selfcriticism and self-enhancement: Theory, research, and clinical implications (pp. 105-122). Washington, DC: American Psychological Association.

Harmon-Jones, E., \& Mills, J. (1999). Cognitive dissonance: Progress on a pivotal theory in social psychology. Washington, DC: American Psychological Association.

Harris, P. (1996). Sufficient grounds for optimism? The relationship between perceived controllability and optimistic bias. Journal of Social and Clinical Psychology, 15, 9-52.

Harris, P.R., \& Napper, L. (2005). Self-affirmation and the biased processing of threatening health-risk information. Personality and Social Psychology Bulletin, 31, 1250-1263.

Heatherton, T.F., Krendl, A.C., Macrae, C.N., \& Kelley, W.M. (2007). A social brain sciences approach to understanding the self. In C. Sedikides \& S. Spencer (Eds.), Frontiers in social psychology: The self (pp. 3-20). New York: Psychology Press.
Heine, S.J. (2003). Self-enhancement in Japan? A reply to Brown and Kobayashi. Asian Journal of Social Psychology, 6, 75-84.

Heine, S.J. (2005). Where is the evidence for pancultural self-enhancement? A reply to Sedikides, Gaertner, \& Toguchi. Journal of Personality and Social Psychology, 89, 531-538.

Heine, S.J., \& Hamamura, T. (2007). In search of East Asian selfenhancement. Personality and Social Psychology Review, 11, 124.

Heine, S.J., Lehman, D.R., Markus, H.R., \& Kitayama, S. (1999). Is there a universal need for positive self-regard? Psychological Review, 106, 766-794.

Heine, S.J., Niiya, Y., \& Harihara, M. (2002). Terror management in Japan. Asian Journal of Social Psychology, 5, 187-196.

Helweg-Larsen, M., \& Shepperd, J.A. (2001). Do moderators of the optimistic bias affect personal or target risk estimates? A review of the literature. Personality and Social Psychology Review, 51, 74-95.

Heppen, J.B., \& Ogilvie, D.M. (2003). Predicting affect from global self-discrepancies: The dual role of the undesired self. Journal of Social and Clinical Psychology, 22, 347-368.

Hobbes, T. (1991). Leviathan. Cambridge, United Kingdom: Cambridge University Press. (Original work published 1651)

Hume, D. (1951). A treatise of human nature (L.A. Selby-Bigge, Ed.). Oxford, United Kingdom: Clarendon Press. (Original work published 1738)

James, W. (1950). The principles of psychology (Vols. 1 \& 2). New York: Dover. (Original work published 1890)

Jenkins, H.M., \& Ward, W.C. (1965). Judgment of contingency between responses and outcomes. Psychological Monographs, 79, $1-17$.

Jones, E.E., \& Berglas, S. (1978). Control of attributions about the self through self-handicapping strategies: The appeal of alcohol and the role of under achievement. Personality and Social Psychology Bulletin, 4, 200-206.

Josephs, R.A., Larrick, R.P., Steele, C.M., \& Nisbett, R.E. (1992). Protecting the self from the negative consequences of risky decisions. Journal of Personality and Social Psychology, 62, 26-37.

Kanagawa, C., Cross, S.E., \& Markus, H.R. (2001). Who am I? The cultural psychology of the conceptual self. Personality and Social Psychology Bulletin, 27, 90-103.

Klar, Y., \& Giladi, E.E. (1997). No one in my group can be below the group's average: A robust positivity bias in favor of anonymous peers. Journal of Personality and Social Psychology, 73, 885901.

Klein, M.P., \& Cooper, K.L. (2007). On the physical health costs of self-enhancement. In E.C. Chang (Ed.), Self-criticism and self-enhancement: Theory, research, and clinical implications (pp. 37-54). Washington, DC: American Psychological Association.

Klein, W.M. (1997). Objective standards are not enough: Affective, self-evaluative, and behavioral responses to social comparison information. Journal of Personality and Social Psychology, $72,763-774$.

Kruger, J. (1999). Lake Wobegon be gone! The below-average effect and the egocentric nature of comparative ability judgments. Journal of Personality and Social Psychology, 77, 221-232.

Kruger, J., \& Dunning, D. (1999). Unskilled and unaware of it: How difficulties in recognizing one's own incompetence lead to inflated self-assessments. Journal of Personality and Social Psychology, $77,1121-1134$. 
Kumashiro, M., \& Sedikides, C. (2005). Taking on board liability-focused feedback: Close positive relationships as a self-bolstering resource. Psychological Science, 16, 732739 .

Kunda, Z. (1987). Motivated inference: Self-serving generation and evaluation of causal theories. Journal of Personality and Social Psychology, 53, 636-647.

Kunda, Z. (1990). The case for motivated reasoning. Psychological Bulletin, 108, 480-498.

Kurzban, R., \& Aktipis, C.A. (2007). Modularity and the social mind: Are psychologists too self-ish? Personality and Social Psychology Review, 11, 131-149.

Kwan, V.S.Y., John, O.P., Kenny, D.A., Bond, M.H., \& Robins, R.W. (2004). Reconceptualizing individual differences in self-enhancement bias: An interpersonal approach. Psychological Review, 111, 94-111.

Langer, E. (1975). The illusion of control. Journal of Personality and Social Psychology, 32, 311-328.

La Rochefoucauld, F. (1827). Reflections: Or sentences and moral maxims (J.W.W. Bund \& J.H. Friswell, Trans.). London: Simpson, Low, Son, \& Marston. (Original work published 1678)

Leary, M.R., \& Baumeister, R.F. (2000). The nature and function of self-esteem: Sociometer theory. In M.P. Zanna (Ed.), Advances in experimental social psychology (Vol. 32, pp. 1-62). San Diego, CA: Academic Press.

Leary, M.R., \& Kowalski, R.M. (1990). Impression management: A literature review and two-component model. Psychological Bulletin, 107, 34-47.

Leary, M.R., Tchividjian, L.R., \& Kraxberger, B.E. (1994). Self-presentation can be hazardous to your health: Impression management and health risk. Health Psychology, 13, 461470.

Leibniz, G.W. (1985). Theodicy (A.M. Farrer \& E.M. Huggard, Trans.). Retrieved August 28, 2007, from http://www.gutenberg.org/etext/ 17147 (Originally published in 1710)

Lerner, J.S., \& Tetlock, P.E. (1999). Accounting for the effects of accountability. Psychological Bulletin, 125, 255-275.

Lockwood, P., \& Kunda, Z. (1997). Superstars and me: Predicting the impact of role models on self. Journal of Personality and Social Psychology, 73, 91-103.

Lord, C.G., Ross, L., \& Lepper, M.R. (1979). Biased assimilation and attitude polarization: The effects of prior theories on subsequently considered evidence. Journal of Personality and Social Psychology, 37, 2098-2109.

Macfarlane, A. (1978). The origins of English individualism: The family, property, and social transition. New York: Cambridge University Press.

Machado, A., \& Silva, F.J. (2007). Toward a richer view of the scientific method: The role of conceptual analysis. American Psychologist, $62,671-681$.

Mandeville, B. (1705). The fable of the bees: or private vices, public benefits (Vol. 1). Oxford, England: Clarendon Press.

Markus, H.R., \& Kitayama, S. (1991). Culture and the self: Implications for cognition, emotion, and motivation. Psychological Review, 98, 224-253.

Martz, J.M., Verette, J., Arriaga, X.B., Slovik, L.F., Cox, C.L., \& Rusbult, C.E. (1998). Positive illusions in close relationships. Personal Relationships, 5, 151-181.

McCrea, S.M., \& Hirt, E.R. (2001). The role of ability judgments in self-handicapping. Personality and Social Psychology Bulletin, $27,1378-1389$.
McKenna, F.P., \& Myers, L.B. (1997). Can accountability reduce or reverse existing illusory self assessments? British Journal of Psychology, 88, 39-51.

Mele, A.R. (2001). Self-deception unmasked. Princeton, NJ: Princeton University.

Mendolia, M., Beach, S.R.H., \& Tesser, A. (1996). The relationship between marital interaction behaviors and affective reactions to one's own and one's spouse's self-evaluation needs. Personal Relationships, 3, 279-292.

Metcalfe, J., \& Mischel, W. (1999). A hot/cool-system analysis of delay of gratification: Dynamics of willpower. Psychological Review, 106, 3-19.

Mezulis, A.H., Abramson, L.Y., Hyde, J.S., \& Hankin, B.L. (2004). Is there a universal positivity bias in attributions? A meta-analytic review of individual, developmental, and cultural differences in the self-serving attributional bias. Psychological Bulletin, 130, 711-747.

Mill, J.S. (2004). Utilitarianism. Retrieved from http://etext.library. adelaide.edu.au/m/mill/john_stuart/m645u/. Adelaide: Australia: eBooks@Adelaide. (Original work published 1863)

Miller, D.T., \& Ross, M. (1975). Self-serving biases in the attribution of causality: Fact or fiction? Psychological Bulletin, 82, 213-225.

Moore, D.A. (2007). Not so above average after all: When people believe they are worse than average and its implications for theories of bias in social comparison. Organizational Behavior and Human Decision Processes, 102, 42-58.

Mussweiler, T. (2003). Comparison processes in social judgment: Mechanisms and consequences. Psychological Review, 110, 472489.

Neiss, M.B., Sedikides, C., \& Stevenson, J. (2006). Genetic influences on level and stability of self-esteem. Self and Identity, 5, 247266.

Newman, L.S., \& Wadas, R.F. (1997). When stakes are higher: Selfesteem instability and self-handicapping. Journal of Social Behavior and Personality, 12, 217-232.

Nietzche, F. (1972). Beyond good and evil (R.J. Hollongdale, Trans.). London: Penguin Books. (Original work published 1886)

Ommundsen, Y. (2001). Self-handicapping strategies in physical education classes: The influence of implicit theories of the nature of ability and achievement goal orientations. Psychology of Sport and Exercise, 2, 139-156.

Ortony, A., \& Turner, T.J. (1990). What's basic about basic emotions? Psychological Review, 97, 315-331.

Parfit, D. (1984). Reasons and persons. Oxford, United Kingdom: Oxford University Press.

Paulhus, D.L. (1998). Interpersonal adaptiveness of trait self-enhancement: A mixed blessing? Journal of Personality and Social Psychology, 74, 1197-1208.

Paulhus, D.L., Graf, P., \& Van Selst, M. (1989). Attentional load increases the positivity of self-presentation. Social Cognition, 7, $389-400$.

Paulhus, D.L., \& John, O.P. (1998). Egoistic and moralistic biases in self-perception: The interplay of self-deceptive styles with basic traits and motives. Journal of Personality, 66, 1025-1060.

Paulhus, D.L., \& Levitt, K. (1987). Desirable responding triggered by affect: Automatic egotism? Journal of Personality and Social Psychology, 52, 245-259.

Pemberton, M., \& Sedikides, C. (2001). When do individuals help close others improve? Extending the self-evaluation maintenance model to future comparisons. Journal of Personality and Social Psychology, 81, 234-246. 
Pettigrew, T.F. (2001). The ultimate attribution error: Extending Allport's cognitive analysis of prejudice. In M.A. Hogg \& D. Abrams (Eds.), Intergroup relations: Essential readings (pp. 162-173). Philadelphia: Psychology Press/Taylor \& Francis.

Pilkington, C.J., Tesser, A., \& Stephens, D. (1991). Complementarity in romantic relationships: A self-evaluation maintenance perspective. Journal of Social and Personal Relationships, 8, 481504.

Preston, C.E., \& Harris, S. (1965). Psychology of drivers in traffic accidents. Journal of Applied Psychology, 49, 284-288.

Pronin, E., Gilovich, T., \& Ross, L. (2004). Objectivity in the eye of the beholder: Divergent perceptions of bias in self versus others. Psychological Review, 111, 781-799.

Pyszczynski, T., Greenberg, J., Arndt, J., \& Schimel, J. (2004). Why do people need self-esteem: A theoretical and empirical review. Psychological Bulletin, 130, 435-468.

Pyszczynski, T., Greenberg, J., \& Goldenberg, J. (2003). Freedom vs. fear: On the defense, growth, and expansion of the self. In M.R. Leary \& J.P. Tangney (Eds.), Handbook of self and identity (pp. 314-343). New York: Guilford.

Raghunathan, R., \& Trope, Y. (2002). Walking the tightrope between feeling good and being accurate: Mood as a resource in processing persuasive messages. Journal of Personality \& Social Psychology, 83, 510-525.

Reed, M.B., \& Aspinwall, L.G. (1998). Self-affirmation reduces biased processing of health-risk information. Motivation and Emotion, 22, 99-132.

Rhodewalt, F., Morf, C., Hazlett, S., \& Fairfield, M. (1991). Selfhandicapping: The role of discounting and augmentation in the preservation of self-esteem. Journal of Personality and Social Psychology, 61, 122-131.

Rhodewalt, F., \& Tragakis, M. (2002). Self-handicapping and the social self: The costs and rewards of interpersonal self-construction. In J. Forgas \& K. Williams (Eds.), The social self: Cognitive, interpersonal, and intergroup perspectives (pp. 121-143). Philadelphia: Psychology Press.

Roese, N.J., \& Olson, J.M. (2007). Better, stronger, faster: Self-serving judgment, affect regulation, and the optimal vigilance hypothesis. Perspectives on Psychological Science, 2, 124-141.

Rorty, R. (1979). Philosophy and the mirror of nature. Princeton, NJ: Princeton University Press.

Ross, M., \& Wilson, A.E. (2002). It feels like yesterday: Self-esteem, valence of personal past experiences, and judgments of subjective distance. Journal of Personality and Social Psychology, 82, 792-803.

Ross, S.R., Canada, K.E., \& Rausch, M.K. (2002). Self-handicapping and the Five Factor Model of personality: Mediation between neuroticism and conscientiousness. Personality and Individual Differences, 32, 1173-1184.

Sanitioso, R.B., Kunda, Z., \& Fong, G. (1990). Motivated recruitment of autobiographical memories. Journal of Personality and Social Psychology, 57, 229-241.

Sanitioso, R.B., \& Niedenthal, P.M. (2006). Motivated self-perception and perceived ease in recall of autobiographical memories. Self and Identity, 5, 73-84.

Sanitioso, R.B., \& Wlodarski, R. (2004). In search of information that confirms a desired self perception: Motivated processing of social feedback and choice of social interactions. Personality and Social Psychology Bulletin, 30, 412-422.

Schmitt, D.P., \& Allik, J. (2005). Simultaneous administration of the Rosenberg self-esteem scale in 53 nations: Exploring the uni- versal and culture-specific features of global self-esteem. Journal of Personality and Social Psychology, 89, 623-642.

Schopenhauer, A. (1966). The world as will and representation (Vol. 2; E.F.J. Payne, Trans.). New York: Dover Publications. (Original work published 1844)

Searle, J. (1983). Intentionality: An essay in the philosophy of mind. New York: Cambridge University Press.

Searle, J. (1997). The construction of social reality. New York: Free Press.

Sedikides, C. (1993). Assessment, enhancement, and verification determinants of the self-evaluation process. Journal of Personality and Social Psychology, 65, 317-338.

Sedikides, C., Campbell, W.K., Reeder, G., \& Elliot, A.J. (1998). The self-serving bias in relational context. Journal of Personality and Social Psychology, 74, 378-386.

Sedikides, C., Gaertner, L., \& Toguchi, Y. (2003). Pancultural selfenhancement. Journal of Personality and Social Psychology, 84, 60-79.

Sedikides, C., Gaertner, L., \& Vevea, J.L. (2005). Pancultural selfenhancement reloaded: A meta-analytic reply to Heine (2005). Journal of Personality and Social Psychology, 89, 531-551.

Sedikides, C., Gaertner, L., \& Vevea, J.L. (2007a). Evaluating the evidence for pancultural self-enhancement. Asian Journal of Social Psychology, 10, 201-203.

Sedikides, C., Gaertner, L., \& Vevea, J.L. (2007b). Inclusion of theoryrelevant moderators yield the same conclusions as Sedikides, Gaertner, \& Vevea (2005): A meta-analytic reply to Heine, Kitayama, \& Hamamura (2007). Asian Journal of Social Psychology, 10, 59-67.

Sedikides, C., \& Green, J.D. (2000). On the self-protective nature of inconsistency/negativity management: Using the person memory paradigm to examine self-referent memory. Journal of Personality and Social Psychology, 79, 906-922.

Sedikides, C., \& Green, J.D. (2004). What I don't recall can't hurt me: Information negativity versus information inconsistency as determinants of memorial self-defense. Social Cognition, 22, 4-29.

Sedikides, C., \& Gregg, A.P. (2001). Narcissists and feedback: Motivational surfeits and motivational deficits. Psychological Inquiry, $12,237-239$.

Sedikides, C., \& Gregg, A.P. (2003). Portraits of the self. In M.A. Hogg \& J. Cooper (Eds.), Sage handbook of social psychology (pp. 110138). London: Sage Publications.

Sedikides, C., Gregg, A.P., \& Hart, C.M. (2007). The importance of being modest. In C. Sedikides \& S. Spencer (Eds.), The self: Frontiers in social psychology (pp. 163-184). New York: Psychology Press.

Sedikides, C., \& Herbst, K. (2002). How does accountability reduce self-enhancement? The role of self-focus. Revue Internationale De Psychologie Sociale, 15, 113-128.

Sedikides, C., Herbst, K.C., Hardin, D.P., \& Dardis, G.J. (2002). Accountability as a deterrent to self-enhancement: The search for mechanisms. Journal of Personality and Social Psychology, 83, 592-605.

Sedikides, C., Horton, R.S., \& Gregg, A.P. (2007). The why's the limit: Curtailing self-enhancement with explanatory introspection. Journal of Personality, 75, 783-824.

Sedikides, C., \& Skowronski, J.J. (2000). On the evolutionary functions of the symbolic self: The emergence of self-evaluation motives. In A. Tesser, R. Felson, \& J. Suls (Eds.), Psychological perspectives on self and identity (pp. 91-117). Washington, DC: American Psychological Association. 
Sedikides, C., \& Strube, M.J. (1997). Self-evaluation: To thine own self be good, to thine own self be sure, to thine own self be true, and to thine own self be better. In M.P. Zanna (Ed.), Advances in experimental social psychology (Vol. 29, pp. 209-269). New York: Academic Press.

Segerstrom, S.C., \& Roach, A. (2007). On the physical health benefits of self-enhancement. In E.C. Chang (Ed.), Self-criticism and selfenhancement: Theory, research, and clinical implications (pp. 3754). Washington, DC: American Psychological Association.

Sherman, D.K., \& Cohen, G.L. (2006). The psychology of self-defense: Self-affirmation theory. In M.P. Zanna (Ed.), Advances in experimental social psychology (Vol. 38, pp. 183-242). San Diego, CA: Academic Press.

Sherman, D.A.K., Nelson, L.D., \& Steele, C.M. (2000). Do messages about health risks threaten the self? Increasing the acceptance of threatening health messages via self-affirmation. Personality and Social Psychology Bulletin, 26, 1046-1058.

Sinclair, L., \& Kunda, Z. (1999). Reactions to a Black professional: Motivated inhibition and activation of conflicting stereotypes. Journal of Personality and Social Psychology, 77, 885-904.

Sinclair, L., \& Kunda, Z. (2000). Motivated stereotyping of women: She's fine if she praised me but incompetent if she criticized me. Personality and Social Psychology Bulletin, 26, 1329-1342.

Skoyles, J. (1998). The Greek revolution. Retrieved September 16, 2006, from http://www.users.globalnet.co.uk/skoyles/index.htm

Smits, T., \& Hoorens, V. (2005). How probable is probably? It depends on whom you're talking about. Journal of Behavioral Decision Making, 18, 83-96.

Solomon, S., Greenberg, J., \& Pyszczynski, T. (1997). Return of the living dead. Psychological Inquiry, 8, 59-71.

Spencer, S.J., Fein, S., \& Lomore, C.D. (2001). Maintaining one's selfimage vis-a-vis others: The role of self-affirmation in the social evaluation of the self. Motivation and Emotion, 25, 41-65.

Spencer, S.J., Fein, S., Wolfe, C.T., Fong, C., \& Dunn, M.A. (1998). Automatic activation of stereotypes: The role of self-image threat. Personality and Social Psychology Bulletin, 24, 1139-1152.

Stapel, D.A., \& Schwinghammer, S.A. (2004). Defensive social comparisons and the constraints of reality. Social Cognition, 22, 147167.

Steele, C.M. (1988). The psychology of self-affirmation: Sustaining the integrity of the self. In L. Berkowitz (Ed.), Advances in experimental social psychology (Vol. 21, pp. 261-302). San Diego, CA: Academic Press.

Steele, C.M., \& Liu, T.J. (1983). Dissonance processes as self-affirmation. Journal of Personality and Social Psychology, 45, 5-19.

Stone, J., \& Cooper, J. (2003). The effect of self-attribute relevance on how self-esteem moderates dissonance processes. Journal of Experimental Social Psychology, 39, 508-515.

Swann, W.B., Jr., Chang-Schneider, C., \& McClarty, K. (2007). Do our self-views matter? Self-concept and self-esteem in everyday life. American Psychologist, 62, 84-94.

Swann, W.B., Jr., Rentfrow, P.J., \& Guinn, J. (2003). Self-verification: The search for coherence. In M. Leary \& J. Tangney. Handbook of self and identity (pp. 367-383). New York: Guilford Press.

Svenson, O. (1981). Are we less risky and more skillful than our fellow drivers? Acta Psychologica, 47, 143-151.

Tafarodi, R.W., Marshall, T.C., \& Milne, A.B. (2003). Self-esteem and memory. Journal of Personality and Social Psychology, 84, 29-45.

Takata, T. (1987). Self-depreciative tendencies in self-evaluation through social comparison. Japanese Journal of Experimental Social Psychology, 27, 27-36.
Tangney, J.P., Baumeister, R.F., \& Boone, A.L. (2004). High self-control predicts good adjustment, less pathology, better grades, and interpersonal success. Journal of Personality, 72, 271-324.

Tatarkiewicz, W. (1976). Analysis of happiness. Warsaw, Poland: Polish Scientific Publishers.

Taylor, S.E., \& Brown, J.D. (1988). Illusion and well-being: A social psychological perspective on mental health. Psychological Bulletin, 103, 193-210.

Taylor, S.E., Lerner, J.S., Sherman, D.K., Sage, R.M., \& McDowell, N.K. (2003). Portrait of the self-enhancer: Well adjusted and well liked or maladjusted and friendless? Journal of Personality and Social Psychology, 84, 165-176.

Tesser, A. (1988). Towards a self-evaluative maintenance model of social behavior. In L. Berkowitz (Ed.), Advances in experimental social psychology (Vol. 21, pp. 181-227). Orlando, FL: Academic Press.

Tesser, A. (2000). On the confluence of self-esteem maintenance mechanisms. Personality and Social Psychology Review, 4, 290299.

Tesser, A., \& Campbell, J. (1982). Self-evaluation-maintenance and the perception of friends and strangers. Journal of Personality, $50,261-279$.

Tesser, A., Campbell, J., \& Smith, M. (1984). Friendship choice and performance: Self-evaluation maintenance in children. Journal of Personality and Social Psychology, 46, 561-574.

Tesser, A., Crepaz, N., Collins, J.C., Cornell, D., \& Beach, S.R.H. (2000). Confluence of self defense mechanisms: On integrating the self zoo. Personality and Social Psychology Bulletin, 26, 1476-1489.

Tesser, A., \& Paulhus, D. (1983). The definition of self: private and public self-evaluation management strategies. Journal of Personality and Social Psychology, 44, 672-682.

Tetlock, P.E., \& Levi, A. (1982). Attribution bias: On the inconclusiveness of the cognition motivation debate. Journal of Experimental Social Psychology, 18, 68-88.

Thibodeau, R., \& Aronson, E. (1992). Taking a closer look: Reasserting the role of the self-concept in dissonance theory. Personality and Social Psychology Bulletin, 18, 591-602.

Tice, D.M. (1991). Esteem protection or enhancement? Self-handicapping motives and attributions differ by trait self-esteem. Journal of Personality and Social Psychology, 60, 711-725.

Tice, D.M., Baumeister, R.F., Shmeuli, D., \& Muraven, M. (2007). Restoring the self: Positive affect helps improve self-regulation following ego depletion. Journal of Experimental Social Psychology, 43, 379-384.

Tice, D.M., Butler, J.L., Muraven, M.B., \& Stillwell, A.M. (1995). When modesty prevails: Differential favorability of self-presentation to friends and strangers. Journal of Personality and Social Psychology, 69, 1120-1138.

Trope, Y. (1979). Uncertainty-reducing properties of achievement tasks. Journal of Personality and Social Psychology, 37, 15051518.

Trope, Y. (1980). Self-assessment, self-enhancement, and task preference. Journal of Experimental Social Psychology, 16, 116-129.

Trope, Y. (1982). Self-assessment and task performance. Journal of Experimental Social Psychology, 18, 201-215.

Trope, Y. (1986). Self-assessment and self-enhancement in achievement motivation. In R.M. Sorrentino \& E.T. Higgins (Eds.), Handbook of motivation and cognition: Foundations of social behavior (Vol. 1, pp. 350-378). New York: Guilford Press. 
Trope, Y., \& Ben-Yair, E. (1982). Task construction and persistence as means for self-assessment of abilities. Journal of Personality and Social Psychology, 42, 637-645.

Trope, Y., \& Pomerantz, E.M. (1998). Resolving conflicts among selfevaluative motives: Positive experiences as a resource for overcoming defensiveness. Motivation and Emotion, 22, 53-72.

Trzesniewski, K.H., Donnellan, M.B., Caspi, A., Moffitt, T.E., Robins, R.W., \& Poultin, R. (2006). Adolescent low self-esteem is a risk factor for adult poor health, criminal behavior, and limited economic prospects. Developmental Psychology, 42, 381-390.

Uhlmann, E.L. (2007). Toward an understanding of motivated discrimination: The roles of constructed criteria and self-perceived objectivity in hiring decisions. Unpublished doctoral dissertation, Yale University, New Haven, CT.

Vazire, S., \& Funder, D.C. (2006). Impulsivity and the self-defeating behavior of narcissists. Personality and Social Psychology Review, 10, 154-165.

Weinstein, N.D., Marcus, S.E., \& Moser, R.P. (2005). Smokers' unrealistic optimism about their risk. Tobacco Control, 14, 55-59.
Wheeler, L., \& Miyake, K. (1992). Social comparison in everyday life. Journal of Personality and Social Psychology, 62, $760-773$.

Willard, G., \& Gramzow, R.H. (in press). Exaggeration in memory: Systematic distortion of self-evaluative information under reduced accessibility. Journal of Experimental Social Psychology.

Wills, T.A. (1981). Downward comparison principles in social psychology. Psychological Bulletin, 90, 245-271.

Wilson, A.E., \& Ross, M. (2001). From chump to champ: People's appraisals of their earlier and present selves. Journal of Personality and Social Psychology, 80, 572-584.

Wood, J.V., Taylor, S.E., \& Lichtman, R.R. (1985). Social comparison in adjustment to breast cancer. Journal of Personality and Social Psychology, 49, 1169-1183.

Yamaguchi, S., Greenwald, A.G., Banaji, M.R., Murakami, F., Chen, D., Shiomura, K., et al. (2007). Apparent universality of positive implicit self-esteem. Psychological Science, 18, 6-8.

Zuckerman, M., \& Tsai, F. (2005). Costs of self-handicapping. Journal of Personality, 73, 411-442. 